\title{
Sub-continental transport mechanisms and pathways during two ozone episodes in northern Spain
}

\author{
G. Gangoiti $^{1}$, A. Albizuri ${ }^{2}$, L. Alonso ${ }^{1}$, M. Navazo ${ }^{1}$, M. Matabuena ${ }^{1}$, V. Valdenebro ${ }^{1}$, J. A. García ${ }^{1}$, and M. M. Millán ${ }^{3}$ \\ ${ }^{1}$ Universidad del País Vasco-Euskal Herriko Unibertsitatea, Escuela Técnica Superior de Ingeniería, Alameda de Urquijo s/n, \\ 48013 Bilbao, Spain \\ ${ }^{2}$ Environment \& Systems, S. A., Luis Briñas 9, $1^{\circ}$ izda, 48013 Bilbao, Spain \\ ${ }^{3}$ Fundación CEAM, Charles Darwin 14, Parque Tecnológico, Paterna, 46980 Valencia, Spain
}

Received: 27 July 2005 - Published in Atmos. Chem. Phys. Discuss.: 25 October 2005

Revised: 16 January 2006 - Accepted: 1 March 2006 - Published: 8 May 2006

\begin{abstract}
Two ozone episodes (occurring in June 2001 and June 2003) in the air quality monitoring network of the Basque Country (BC) are analyzed. The population information threshold was exceeded in many stations (urban, urbanbackground and rural). During this type of episodes, forced by a blocking anticyclone over the British Isles, ozone background concentrations over the area increase after the import of pollution from both, the continental Europe and the western Mediterranean areas (Gangoiti et al., 2002). For the present analysis, emphasis is made in the search for transport mechanisms, pathways and area sources contributing to the build-up of the episodes. Contributions from a selection of 17 urban and industrial conglomerates in the western European Atlantic (WEA) and the western Mediterranean (WM) are shown after the results of a coupled RAMS-HYPACT modelling system. Meteorological simulations are tested against both the high-resolution wind data recorded at the $\mathrm{BC}$ coastal area by a boundary layer wind-profiler radar (Alonso et al., 1998) and the wind soundings reported by the National Centres of Meteorology at a selection of European and northAfrican sites. Results show that during the accumulation phase of the episodes, background ozone concentrations increase in the whole territory as a consequence of transport from the Atlantic coast of France and the British Channel. For the peak phase, intrusions from new sources, located at the Western Mediterranean, Southern France, Ebro Valley, and, occasionally, the area of Madrid are added, resulting in a further increase in the ozone concentrations. Direct day and night transport within the north-easterly winds over the sea from the WEA source region, and night-time transport within the residual layer over continental areas (southern France, the Ebro Valley, and central Iberia) modulate the import sequence of pollutants and the local increase of ozone concentrations. The alternative direct use of low resolution meteo-
\end{abstract}

Correspondence to: G. Gangoiti

(g.gangoiti@ehu.es) rological data for the estimation of back-trajectories shows a more simple transport scheme with no contributions neither from the Western Mediterranean nor from the Madrid area.

\section{Introduction}

Blocking anticyclones over the British Isles and their subsequent evolution eastwards have been associated with subcontinental transport of photochemical pollution into the BC (Gangoiti et al., 2002). This meteorological scenario is yearly recurrent, more frequently in late spring, and it is behind most of the ozone exceedances of the population information threshold (hourly average of $180 \mu \mathrm{g} / \mathrm{m}^{3}$ ) of the current EU Directive 2002/3/EC (Albizuri, 2004), occurring in the $\mathrm{BC}$ during consecutive days. Exceedances are detected throughout the entire air quality monitoring network (a total of 37 coastal and inland stations) covering the whole BC area, where ozone concentrations above $120 \mu \mathrm{g} / \mathrm{m}^{3}$ are reported by all stations and the population information threshold is exceeded in a significant fraction of them. The relative high frequency of blocking anticyclones in the WEA region is the main cause of the exceedances of the 2010 target value for the protection of human health (maximum daily 8 -h mean of $120 \mu \mathrm{g} / \mathrm{m}^{3}$ not to be exceeded on more than 25 days per calendar year, averaged over three years): Table 1 shows a summary of ozone exceedances in the BC from 1999 to 2003 (Albizuri, 2005).

Two ozone episodes, with a duration of 2-3 days each, are analyzed here. They were detected in the $\mathrm{BC}$ air quality monitoring network, and occurred after the evolution of WEA blocking anticyclones in June 2001 and June 2003. The selection of these episodes was decided after a detailed analysis of the daily ozone concentrations throughout the $\mathrm{BC}$ network. Both episodes are exceptional because of their duration, extension, and the high concentrations attained: ozone above $120 \mu \mathrm{g} / \mathrm{m}^{3}$ was reported by all the stations during 2-3

Published by Copernicus GmbH on behalf of the European Geosciences Union. 
Table 1. Summary of ozone exceedances during the period 1999-2003 at the monitoring network of the Basque Country (exceedances above target values for the year 2010 and above the information threshold are marked over a coloured background).

\begin{tabular}{cccccc}
\hline Year & Maximum daily 8 -hour mean $>120 \mu \mathrm{g} / \mathrm{m}^{3}$ & Hourly mean $>180 \mu \mathrm{g} / \mathrm{m}^{3}$ \\
1999 & Number of days & 3 years average & $\begin{array}{c}\text { No. of } \\
\text { days }\end{array}$ & $\begin{array}{c}\text { No. of } \\
\text { hours }\end{array}$ & $\begin{array}{c}\text { No. of } \\
\text { stations }\end{array}$ \\
\hline 2000 & 37 & 2 & 7 & 2 \\
2001 & 23 & 30 & 0 & 0 & 0 \\
2002 & 17 & 24 & 1 & 2 & 6 \\
2003 & 64 & 37 & 12 & 48 & 20 \\
\hline
\end{tabular}

days of each episode, and the population information threshold was exceeded during 2 days of each episode on 10 stations for the June 2003 episode, and on 3 stations for the June 2001 episode. The 2001 episode was followed by the most severe ozone episode of the year in west-central Europe (24-27 June) (de Leeuw, and Bogman, 2001), while, at the same time, the highest ozone concentrations in northern Iberia and the $\mathrm{BC}$ were decreasing: the high pressure system over the European continental area gave rise to the most extended, long-lasting, and highest ozone concentrations of the year 2001 in Europe. The June 2003 episode is the second more severe ozone episode of the year in the BC. During the first half of August 2003, an exceptionally longlasting ozone episode occurred in all over Europe, including the Iberian Peninsula and excluding the northern European countries (Fiala et al., 2003). The meteorology was also exceptional with the persistence of a high pressure system over the European continental area (the period of stability lasted for more than 2 weeks, with subsidence inversions and formation of long-lasting reservoir layers of aged pollutants), and the registered temperature records with night and day maxima. The evolution of the ozone concentrations during the June 2003 episode in the BC, although shorter and less severe than the one in August, shows a more standard pattern regarding the "normal" evolution of WEA blocking anticyclones and their recurrent formation (Gangoiti et al., 2002), "never" lasting for more than 3-to-4 days.

Numerical simulations, including high (spatiotemporal) resolution mesoscale meteorology and dispersion of passive tracers (single or multiple backward and forward trajectories) in a Lagrangian framework, have frequently been used to identify source-receptor relationships at both regional and inter-continental (IC) scales (Kallos et al., 1998; Alonso et al., 2000 ; Gangoiti et al., 2001, 2002; Palau et al., 2004). Complex circulatory systems and the coupling between the various atmospheric motion scales can be effectively simulated by these types of modelling systems. They can be used to document the transport of pollutants at a regional to inter-continental scale, under complex scenarios such as the one presented here, which results from the irruption of blocking anticyclones in a coastal and mountainous environment. Among other abilities, this type of modelling system can reproduce adequately the onset and decay of land and sea-breezes, the topographic forcing, the fine-scale layering of the lower troposphere, and the sharp variations in both time and space of stability within the planetary boundary layer over a non-homogeneous surface. Global, lower resolution meteorological data provided by the National Centers for Environmental Prediction (NCEP) and the European Centre for Medium-Range Weather Forecasting (ECMWF), among others, have also been used to track passive tracers using Lagrangian particle dispersion models with the aim of documenting the IC and regional transport of pollutants (Brönnimann et al., 2001; Draxler, 2003).

The Regional Atmospheric Modelling System (RAMS version 4.4.0, Pielke et al., 1992) has been used here to simulate the observed meteorological processes at a local-toregional scale and at a sufficient temporal resolution. Latest versions of the code, as the one used here, allow parallelization, which helps to shorten computer time. Wind and turbulence fields obtained by RAMS are fed to the HYbrid Particle Concentration and Transport (HYPACT) model, a combination of a Lagrangian particle model and a Eulerian concentration transport model (Tremback et al., 1993), to track the evolution of plumes (passive tracer) released from a selection of urban and industrial conglomerates in the WEA and the WM.

Thus, the purpose of this manuscript is to elucidate the origin of the $\mathrm{O}_{3}$ and its precursors during the episodes (source-receptor relationships) and to search for the 


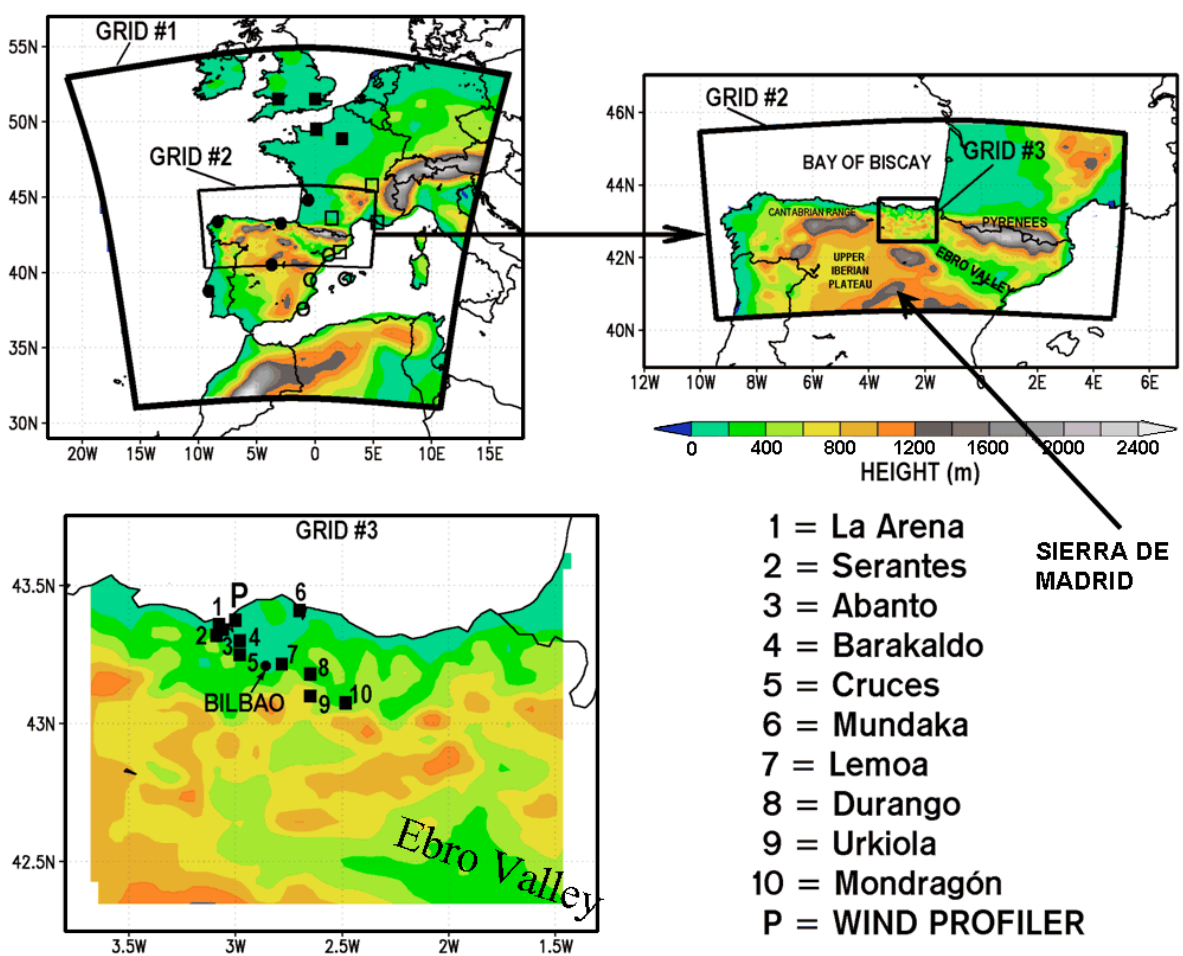

Fig. 1. Topographic map of the three domains (grid 1, 2 and 3) used by RAMS and HYPACT. (Top-left) The selected European sources of pollution for the simulations are represented with closed squares and circles (regions $\mathrm{A}$ and $\mathrm{B}$, respectively), and open squares and circles (regions C and D). (Bottom-left) The Basque Country is completely included in grid 3, where the upper Ebro valley, the location of the WPR (marked P) and the selected ozone monitors (1-to-10) have also been represented. (Top-right) Main topographic features surrounding the Basque Country are represented in the intermediate grid \#2, and (bottom-right) the list of the ozone stations.

local-to-continental transport mechanisms operating during the build-up of the episodes. This analysis will contribute to set up more accurate short-term forecasting schemes for the early warning of episodes. In addition, the knowledge of the $\mathrm{O}_{3}$ contribution from long range transport to local episodes can help to establish plans for reduction of precursor emissions at the continental scale, leading to effective reductions in ozone concentrations. Section 2 is devoted to the area description, including the topography, position of the ozone monitors, main local sources of precursors, and evolution of the ozone concentration during the episodes. Section 3 describes the modelling system and the selected initial and boundary conditions. Section 4 compares the results of the RAMS simulations with the output of a high resolution wind profiler radar (WPR) at the coastal area of the BC and the wind soundings reported by the National Centres of Meteorology (NCM) at a selection of sites covering the domain of simulation. Section 5 shows the results of the HYPACT simulations and discusses the transport mechanisms and pathways during the episode. These high-resolution results obtained with the RAMS-HYPACT modelling system are also compared with the backward trajectories calculated on-line at the Air Resources Laboratory (ARL) web site, using the NOAA HYSPLIT model (Rolph, 2003; Draxler and Rolph,
2003). Finally, Sect. 6 presents the summary and the conclusions.

\section{Area description and observed ozone concentrations}

The BC is located in the north-centre of the Iberian Peninsula between two major mountain ranges: the Pyrenees, at the East, and the Cantabrian Range, at the West (Fig. 1). A complex of smaller mountains and valleys with different orientations conforms the transition between the lower valleys at the sea side, and the two main airsheds in northern Iberia: the upper Iberian plateau, which drains into the Atlantic Ocean, and the Ebro valley, which drains into the Mediterranean. The city of Bilbao and its associated industrial area, located along an estuary that runs nearly $16 \mathrm{~km}$ from the centre of the city to the sea in a SE-NW direction, is the most populated area in the $\mathrm{BC}$ and the most important source of pollution from industrial activities (Gangoiti et al., 2002) and traffic. Other industrial activities, with lower emission rates and a more local impact, are located in small inland valleys (viz. Durango, Lemoa and Mondragon in Fig. 1) and conurbations of smaller cities (not shown). Road traffic has been identified as the main source of $\mathrm{NO}_{\mathrm{x}}$ in the $\mathrm{BC}$, with the 

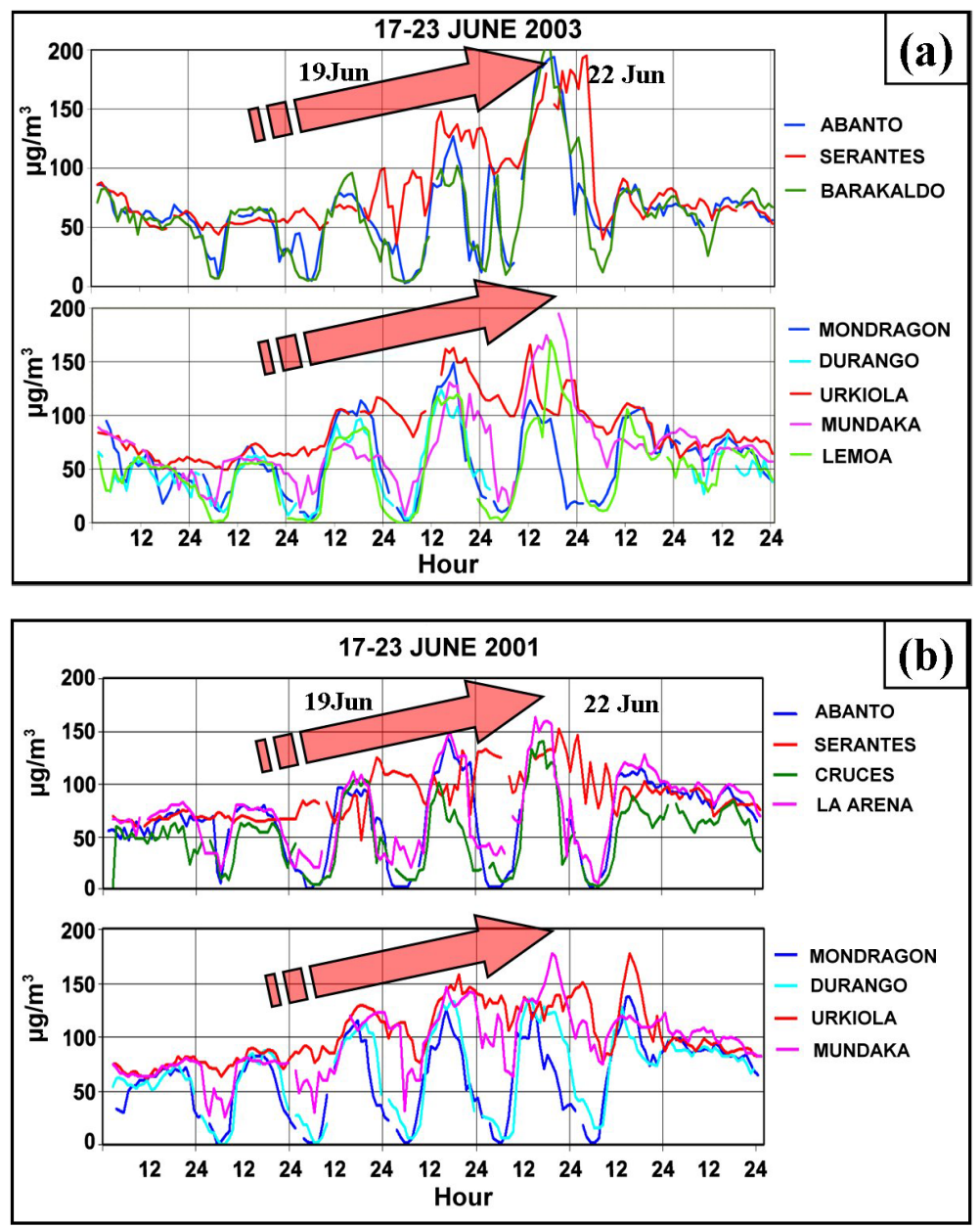

Fig. 2. Ozone concentration time sequences throughout the episodes (a) in June 2003 and (b) in June 2001 at a selection of urban background stations in the Bilbao estuary (upper graphs: stations 1-to-5 in Fig. 1) and out of the estuary (lower graphs: stations 6-to-10 in Fig. 1) at rural and urban background stations. Ozone concentrations follow a similar evolution for all monitors, including those located at large distances (80-100 km) from each other.

main source area in the Bilbao estuary and secondary sources in smaller cities (Environment and Systems, 1999). For the non-methane volatile organic compounds (VOCs), road traffic in the Bilbao estuary is again the most important area source, but considering the complete territory, the biogenic emissions distributed in the forest and agricultural areas contribute with a higher percentage (78\% biogenic vs. $22 \%$ traffic) of the total non-methane VOC emissions (Environment and System, 1999). This has important implications in the concentration of both ozone and precursors, in urban and rural areas (Navazo et al., 2005; Durana et al., 2005).

Figure 1 shows the locations of a selection of stations in the air quality network (sites marked 1-to-10), together with the site of a wind profiler radar WPR (marked P) and the city of Bilbao. The BC is completely included in grid 3 (Fig. 1), and occupies the north-central area within the domain. Figure 1 also shows the topography and boundaries of the three nested domains used for the mesoscale model RAMS (Pielke et al., 1992): grids 1-to-3, with increasing resolutions of 48, 12 and $3 \mathrm{~km}$, respectively. The 17 urban locations selected for the dispersion simulation performed by HYPACT (Tremback et al., 1993) are also shown in the figure (on grid 1).

Time series of ozone concentrations measured by the air quality monitoring stations are shown in Fig. 2: concentrations began to rise on 19 June (accumulation phase: 19-20 June), reached the highest concentrations on 21 June (peak phase) and decreased on the 22nd (dissipation phase), for the episode in June 2003 (Fig. 2a). A similar evolution was observed for the episode in June 2001 (Fig. 2b) with a peculiar coincidence of dates for all three phases. The upper panels, in Figs. 2a and b, correspond to stations within the estuary of Bilbao. Except for the Serantes station (red line), which is a suburban elevated station located on top of a mountain (451 $\mathrm{m}$ height) at the coastline, they all are urban background stations. The lower panels (Figs. 2a and b) show ozone time series for stations out of the Bilbao estuary: two 

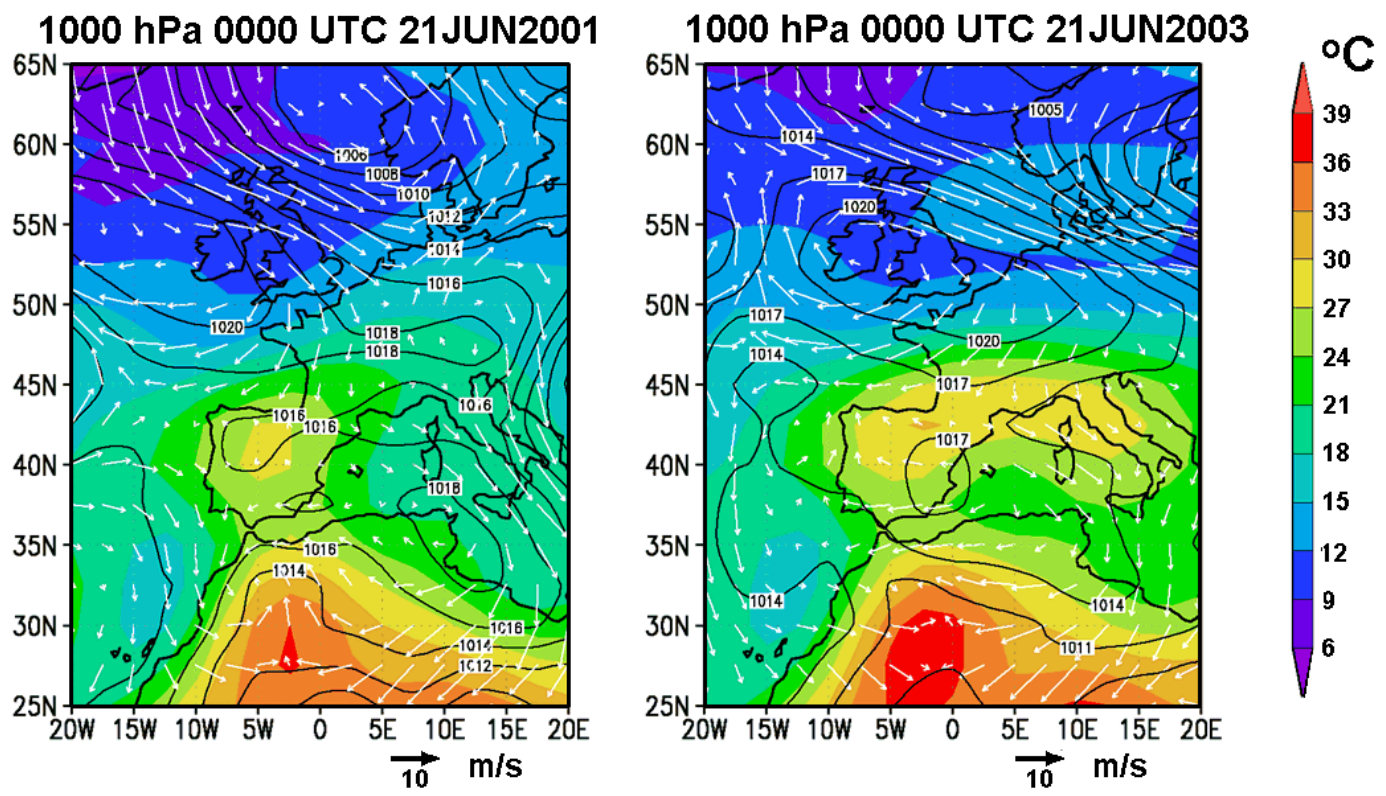

Fig. 3. NCEP reanalysis sea-level pressure (contour lines), temperature (shaded colours) and wind field on the $1000 \mathrm{hPa}$ surface, during the peak day (at 00:00 UTC) of both episodes. A similar synoptic scenario is shown: blocking anticyclones and north-easterly winds prevail at the Bay of Biscay and northern Spain.

rural background stations (Mundaka at the coastal strip and Urkiola at $700 \mathrm{~m}$ height, on top of an inland mountain) and the urban background stations of the villages of Durango, Mondragon and Lemoa, located in populated inland valleys. Ozone concentrations follow a similar 3-phase evolution for the whole territory. Significant differences can be observed between in-valley and elevated stations: night-time ozone concentrations at elevated sites remain high, while the rest of concentrations deplete by titration from local fresh emissions from in-valley sources. This type of behaviour has already been discussed by Millán et al. (2000) in eastern Iberia and Gangoiti et al. (2002) at the northern coast. Vertical layering of ozone and other fresh and aged pollutants was documented during a flight campaign in the $\mathrm{BC}$ under a typical summer synoptic scenario Alonso et al. (2000): the results showed the importance of the ozone reservoir layers transported aloft from the WEA region, in order to explain the observed ground concentrations of ozone in the BC coastal area and inland mountains.

\section{High resolution simulations: initial and boundary conditions.}

RAMS simulations were performed under non-homogeneous initialization with non-stationary boundary conditions: fourdimensional data assimilation was used for the model run, nudging the boundaries of the larger domain (grid 1, in Fig. 1) to the conditions given by the NCEP reanalysis daily data at 00:00, 06:00, 12:00 and 18:00 UTC $\left(2.5^{\circ} \times 2.5^{\circ}\right.$ latitude-longitude grid resolution, provided by the NOAACIRES Climate Diagnostics Center, Boulder, Colorado, USA, at the Web site http://www.cdc.noaa.gov/). The run was performed continuously, from 00:00 UTC on the 18th June through 00:00 UTC on the 23rd for the 2001 and 2003 episodes. Two-way nesting was allowed between the 3 grids (Fig. 1). In the vertical, 34 levels with variable resolutions are used for all domains, with a total coverage of $12000 \mathrm{~m}$. A vertical resolution of $25-40 \mathrm{~m}$ is selected close to the ground, and of $1000 \mathrm{~m}$ at the highest levels. The topography and land cover of the three domains were interpolated to the model grids from the USGS global 30" latitude-longitude grid resolution database (available at http://edcdaac.usgs.gov/glcc/glcc.asp). Raw sea surface temperature (SST) weekly data, with a latitude-longitude resolution of $1^{\circ} \times 1^{\circ}$, from the NCEP Reynolds SST dataset (Reynolds and Smith, 1994) were interpolated in time during the model run to the model grids (SST data available at the Jet Propulsion Laboratory FTP site ftp://podaac.jpl.nasa. gov/pub/sea_surface_temperature/reynolds/oisst).

Hourly meteorological fields estimated by RAMS are forwarded to the HYPACT model to perform the dispersion evaluation of a passive tracer. During the simulations, the emitted particles do not undergo chemical transformations or deposition processes. A total of 17 sources of vertical emission lines (0-300 $\mathrm{m}$ height) were selected (Fig. 1). The variable height of the particle release, from surface to $300 \mathrm{~m}$ AGL, accounts for the great variety in the effective heights of emission from urban and industrial sources. In order to deal with all possible sub-continental to local transport 


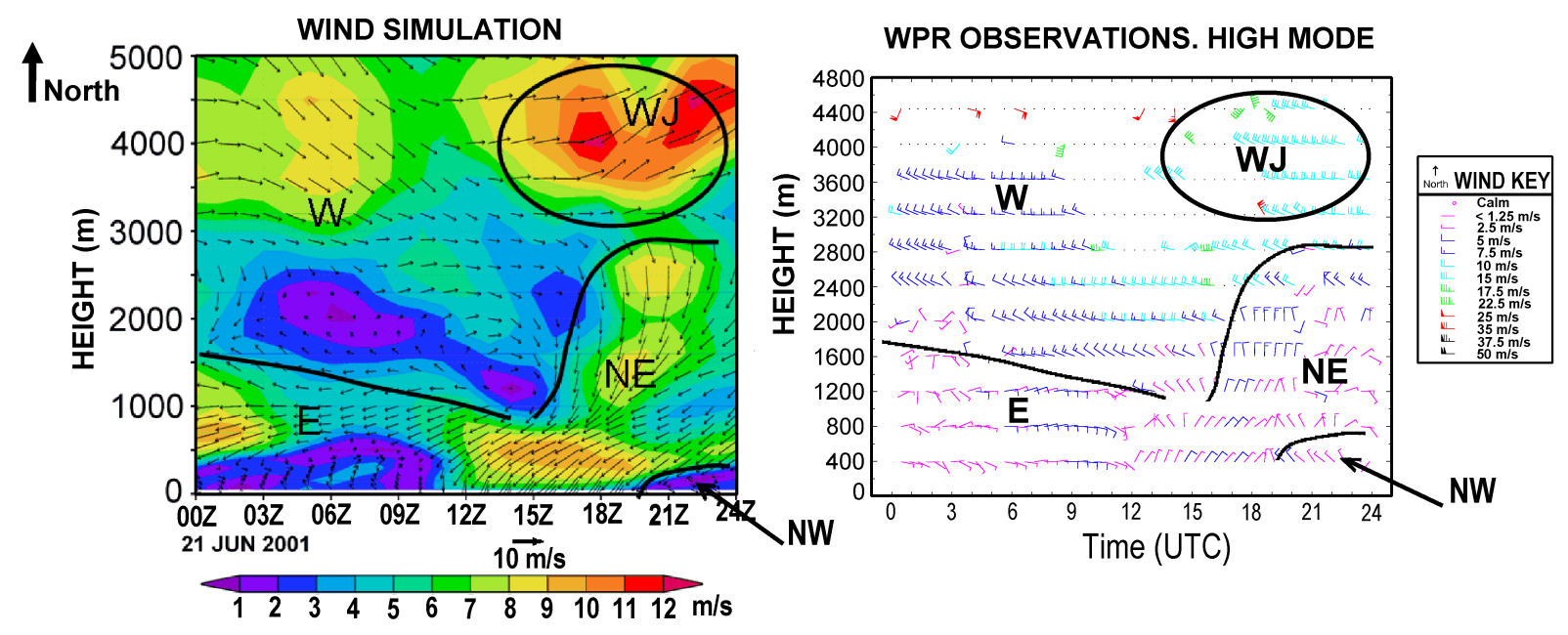

Fig. 4. (Left) Time sequence of simulated wind profiles at the highest resolution grid (\#3) on the vertical of the WPR site (marked P in Fig. 1) during the peak day of the June 2001 episode: the magnitude of the wind velocity is represented in shaded colour and the vector scale is shown at the bottom. (Right) The high mode - low resolution - WPR observations (right) for the same period. The solid black lines separate different air masses (see Sect. 4).

mechanisms working in the area, the coastal (Mediterranean and Atlantic) and inland sources cover an area of different weather and wind regimes in western and southern Europe during the warm season. These sources have been grouped into 4 areas as follows:

- Region A (four cities in the north WEA): London, Cardiff, Le Havre, and Paris.

- Region B (five cities in the south WEA): Bordeaux, Bilbao, A Coruña, Lisbon, and Madrid.

- Region C (four cities in the north WM): Lyon, Toulouse, Marseille, and Barcelona.

- Region D (four cities in the central and south WM): Tarragona, Valencia, Palma, and Cartagena.

Particle release starts $6 \mathrm{~h}$ after the RAMS's initial time of simulation. Particles are emitted every $90 \mathrm{~s}$, for 4 days (06:00 UTC on 18 June to 06:00 UTC on 22 June, for both episodes). Particle positions (a maximum of 192000 particles for the five cities - region B - simulations, and 153600 for each of the four cities simulations) are tracked for the whole period, up to 00:00 UTC on 23 June. The conditions selected are not intended to draw conclusions on actual pollutant burdens. However, they allow us to investigate in detailpreferred pathways, travel times, accumulation areas (larger time of residence) and venting mechanisms for the export of pollutants to neighbouring regions.

\section{Meteorology: observed and simulated wind fields}

During both episodes a blocking anticyclone deepens over the British Isles during the accumulation and peak phases.
Figure 3 shows NCEP reanalysis sea level pressure (contourlines), temperature (shaded colors) and wind field at the $1000 \mathrm{hPa}$ surface, during the peak day of both episodes. North-easterly winds are forced over northern Iberia, bringing continental air from the English Channel and western France. These regions have already been shown to contribute to the build-up of ozone episodes in northern Spain: Gangoiti et al. (2002) describe a similar episode in June 1996. However, apart from these direct European continental trajectories, we have found some hidden pathways responsible for the import of ozone and precursors from other source areas (western Mediterranean and central Iberia). The dissipation phase begins when the high pressure moves eastward and a trough of low pressure extends into the Bay of Biscay, bringing fresh Atlantic air into the area (not shown).

RAMS ability to reproduce local scale atmospheric processes, actually occurring during the episodes was tested by comparing its wind results against the wind profiles measured by the WPR at the Bilbao port area. Figure 4 shows the observed and simulated wind sequences during the peak day of the June 2001 episode. RAMS has reproduced adequately the WPR high-mode observations (vertical resolution of $400 \mathrm{~m}$ ): the easterly winds (W) and the jet (WJ) blowing at height are in good agreement.

Low level easterly winds, forced by the anticyclone over the British Isles and the NE'ly low level jet, caused by sinking of the inversion and the onset of a strong sea-breeze after midday, are also well represented by the model. During the night-time (20:00 UTC) a shallow coastal stable layer (NW in Fig. 4) irrupts at lower levels ( $300 \mathrm{~m}$ depth), preceding the local drainage flows of the Bilbao estuary, which develop during the next morning (not shown). For the remaining days in the June 2001 and June 2003 episodes, comparisons 

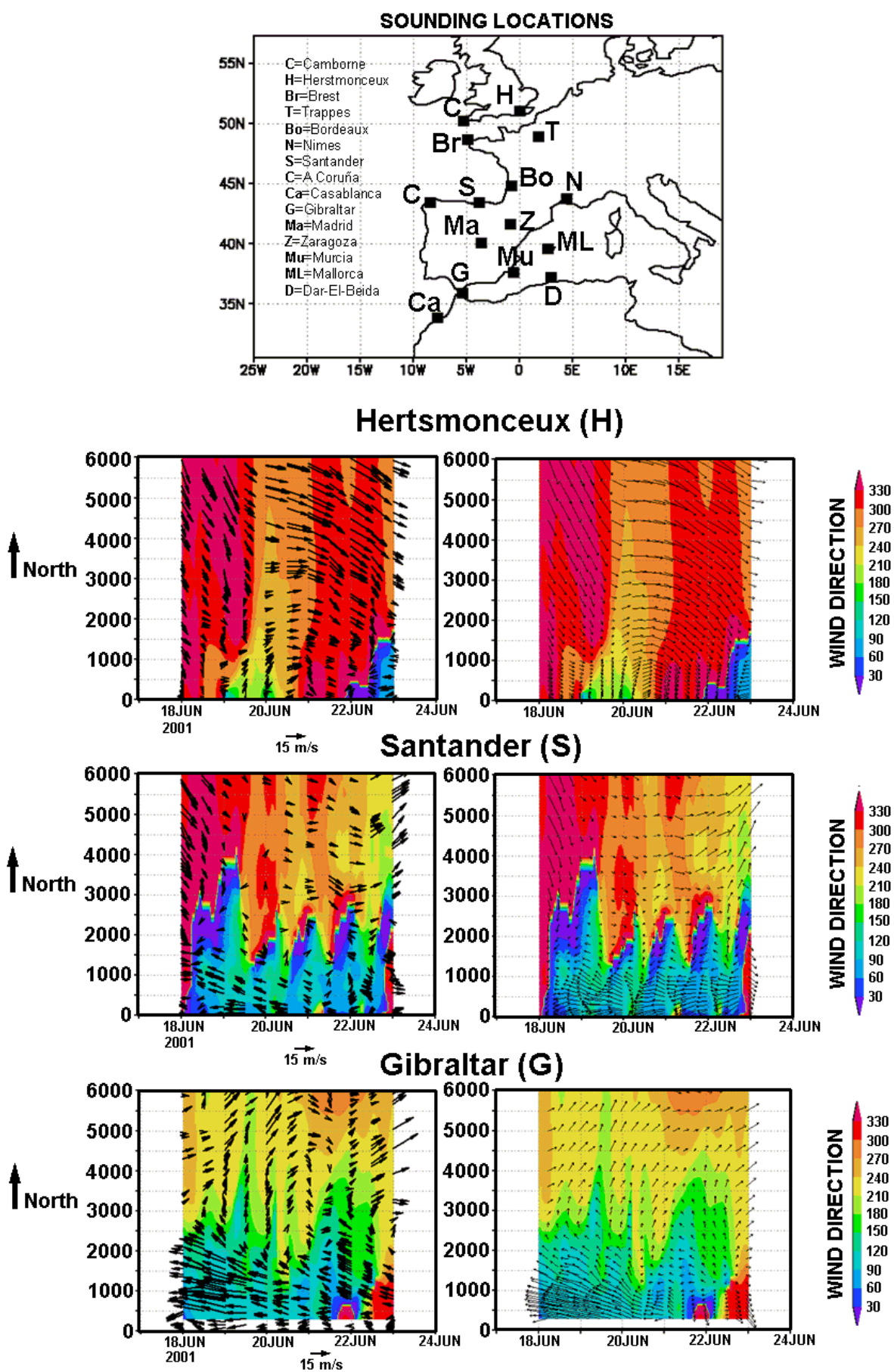

Fig. 5. (Top) Location of the NMC sounding sites used to evaluate the model output at the continental scale. (Bottom-left: three panels) Sequence of wind profiles observed at a selection of three NMC sounding sites during the period of simulation (5 days) of the June 2001 episode: vectors represent wind speed and direction. The scale of the wind magnitude is shown at the bottom of each panel. (Bottom-right: three panels) Same wind profiles estimated by RAMS. Shaded colours (left and right panels) represent wind direction estimated by RAMS.

between model and WPR data show similar results: long periods of excellent agreement and short intervals with differences in wind speed, wind direction, or both, mostly associated with transitional periods after sudden changes in meteo- rological conditions that the model could not capture appropriately.

Mesoscale simulations performed by RAMS were also compared with wind soundings from a selection of NCM 

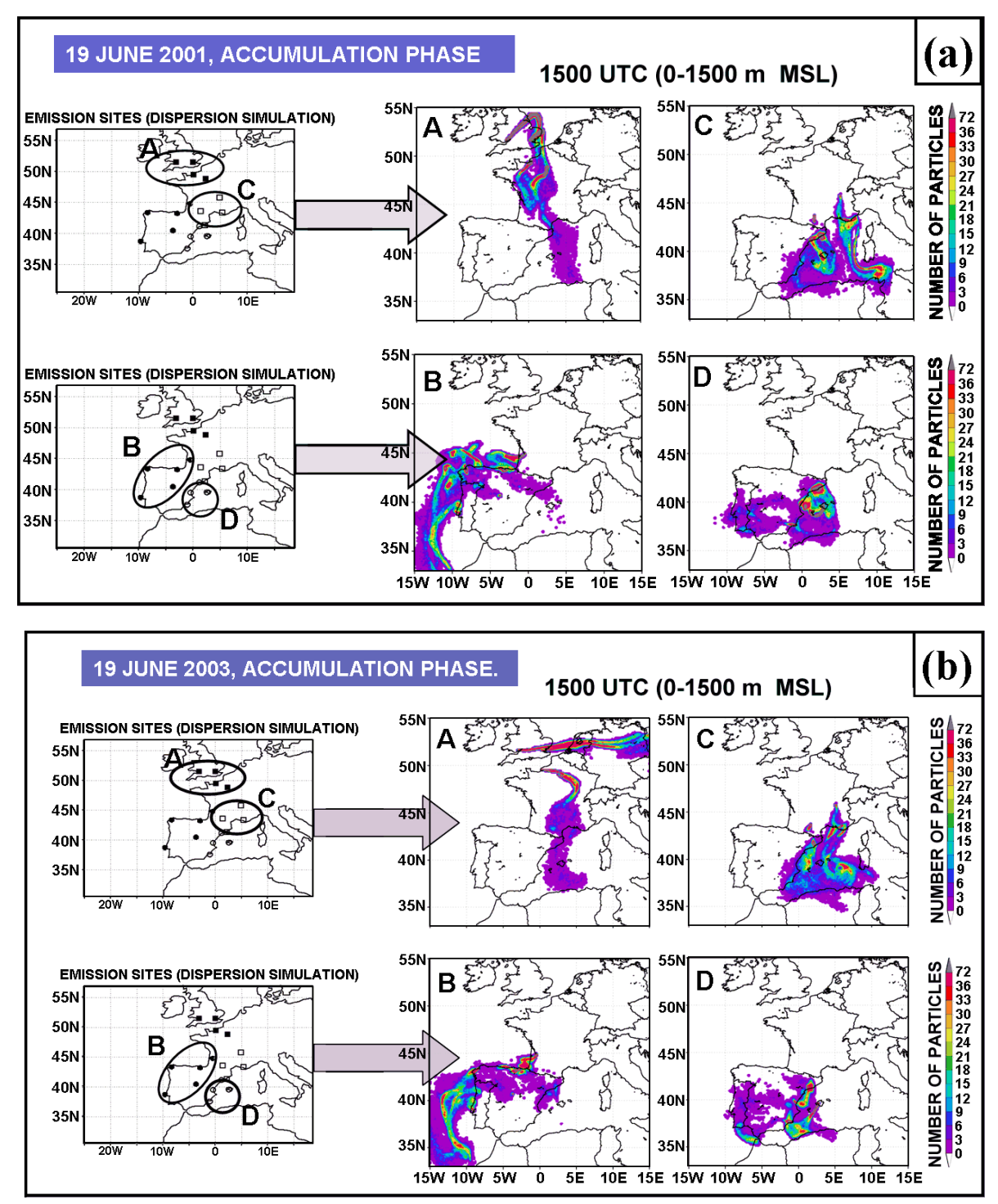

Fig. 6. (a) Burden of tracer particles in the lower troposphere (0-1500 m MSL) emitted from the selection of European sources located in the Atlantic (A-B) and WM regions (C-D) during the accumulation phase of the June 2001 episode. (b) Same for the June 2003 episode.

sites. Neither the time coverage (usually 2 soundings per day) nor the vertical resolution of the soundings are as good as the WPR observations, but the comparison is useful to test the capacity of the model to reproduce the actual wind field at the continental scale: the accuracy of the HYPACT dispersion simulation at the regional-to-continental scale relies on an accurate meteorological simulation at the whole domain. The selected NCM sounding sites are shown in Fig. 5 (top panel): they are located in western Europe and northern Africa, covering the region of simulation. The sequences of wind profiles during the June 2001 episode, for the stations of Herstmonceaux (H), Santander (S), and Gibraltar (G), covering the largest domain from north to south, are shown in Fig. 5 (bottom left three panels): RAMS results (bottom right three panels) follow the main wind variations docu- mented by the NMC sounding stations. In this respect, the Hertsmonceaux station, located on flat terrain, shows good agreement at all levels with the modelled winds. To contrast, at the Gibraltar site, in a narrow corridor between the steep mountains in northern Africa and southern Iberia, the simulated winds and observations show the largest differences at lower levels. These discrepancies are related to the numerical terrain smoothing performed by the model at that site: there are wind observations down to the sea level for the radio-sounding data, while there are no model estimations under $300 \mathrm{~m}$ MSL, which is the lowest terrain elevation of the model grid at the Straits of Gibraltar. The main consequence of this fictitious obstruction of the strait for our set of simulations is an underestimation of the Mediterranean discharge into the Atlantic (Levante winds) at lower levels, 

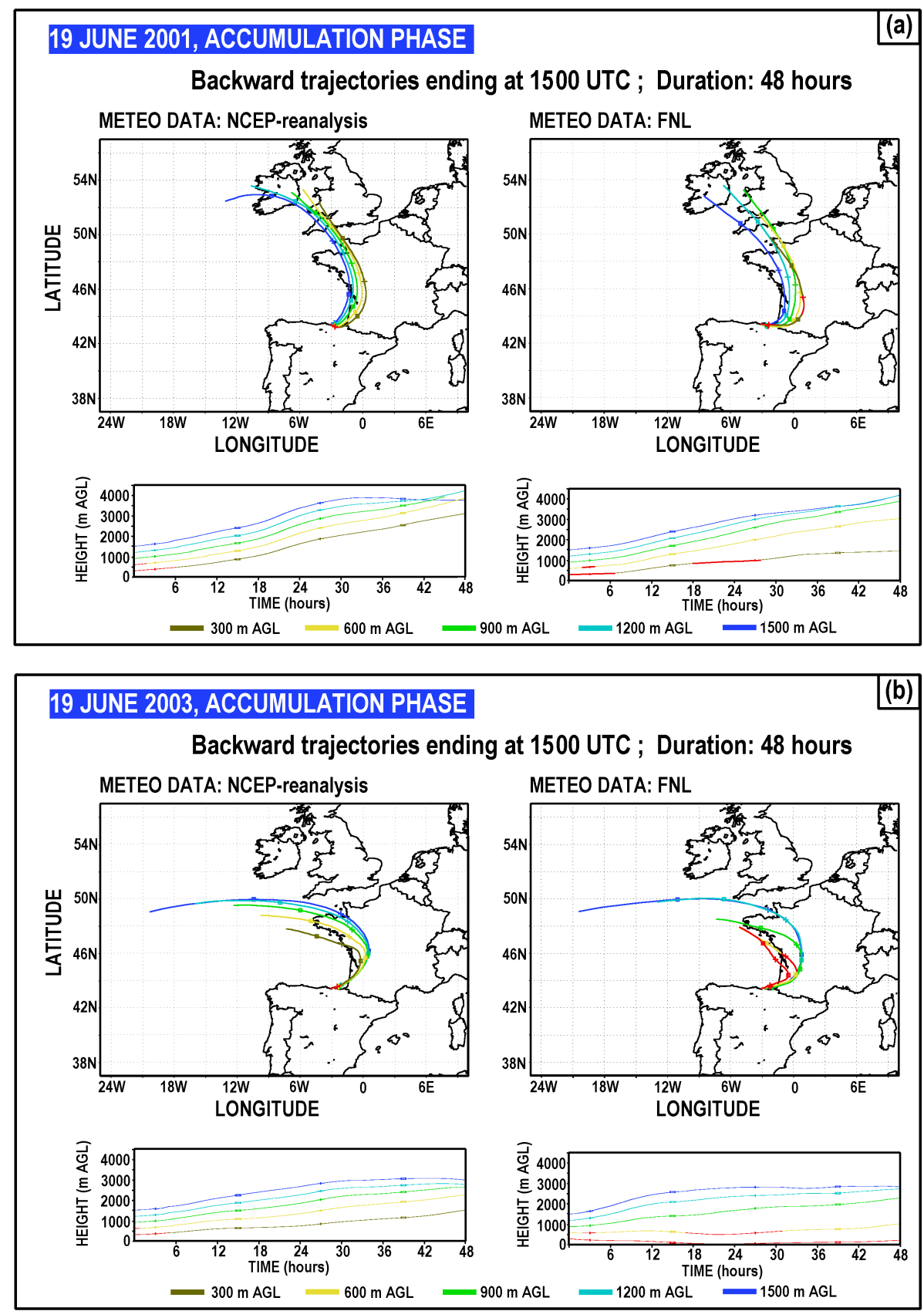

Fig. 7. (a) Back-trajectories arriving at the vertical (300, 600, 900, 1200 and $1500 \mathrm{~m}$ AGL) of the Basque Country coastal area during the accumulation phase (15:00 UTC, 19 June) of the 2001 episode, calculated using the NCEP-reanalysis (left) and the FNL (right) meteorological data. Trajectories are shown in a longitude-latitude (upper graphs) and time-height (lower graphs) projections . Crosshairs and open squares on the trajectories mark midday and midnight times, respectively (b) Same for the June 2003 episode (15:00 UTC, 19 June).

which is noticeable when Levante winds weaken, at the end of the episode. A similar behaviour was observed during the June 2003 episode (not shown). Most of the observed differences for the rest of the NMC stations (not shown), when they exist, are centred at lower levels (surface and planetary boundary layer). We did not find this type of discrepancies with the WPR observations: as all NMC stations are out of the highest resolution region of the model, the differences are probably caused by the model's lack of a sufficient spatial resolution at the specific sites. 

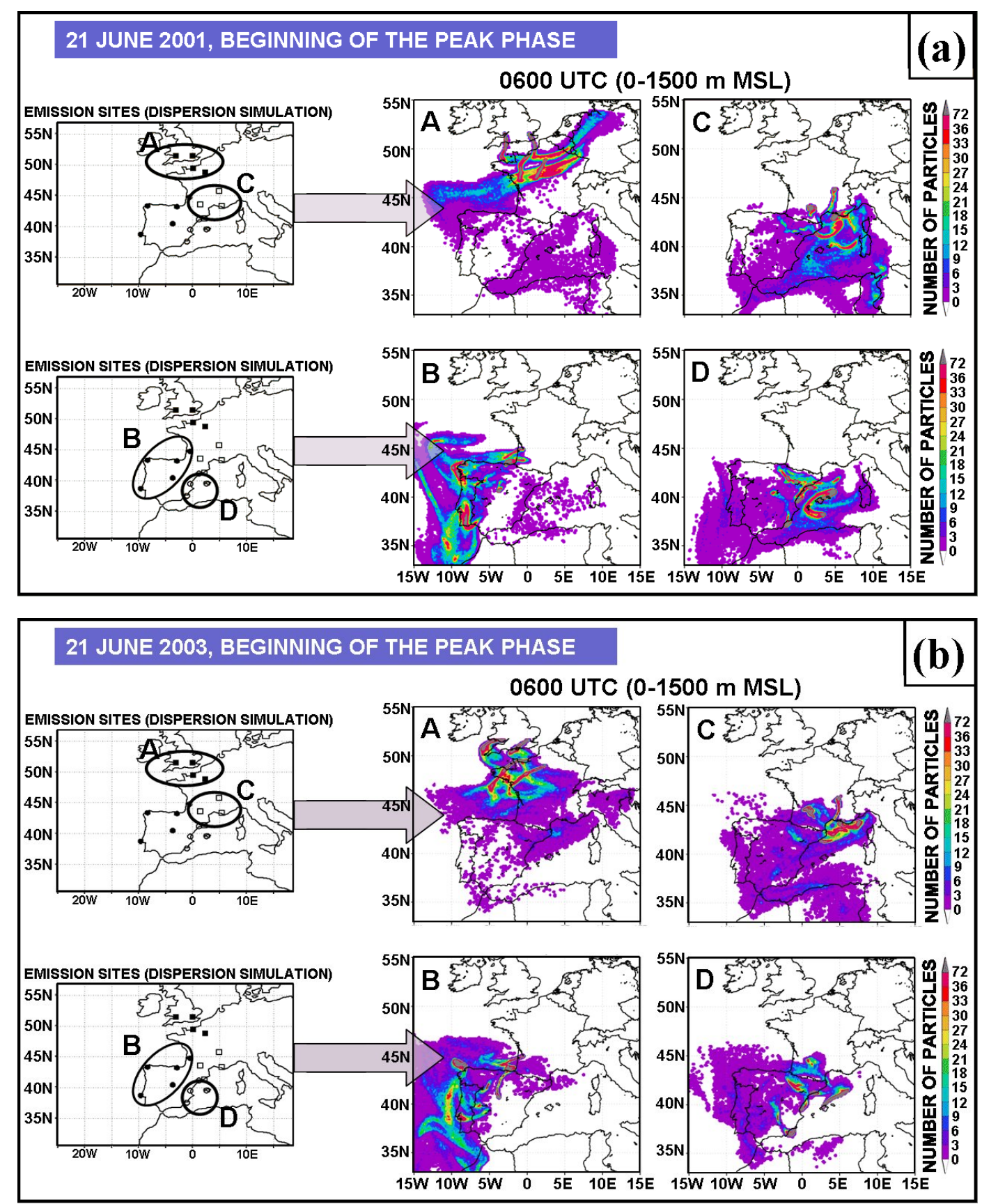

Fig. 8. (a) Burden of tracer particles in the lower troposphere (0-1500 m MSL) emitted from the selection of European sources located in the Atlantic (A-B) and WM regions (C-D) during the early morning of the peak day of the June 2001 episode. (b) Same for the June 2003 episode.

\section{Dispersion: mechanisms and pathways for the import of ozone and precursors into the $\mathrm{BC}$.}

\subsection{Accumulation phase}

The HYPACT simulation results show that during the accumulation phase of both episodes most of the pollution burden over the $\mathrm{BC}$ can be attributed to sources on the Atlantic coast of France as well as local sources: shaded colour scaling in Fig. 6 represents tracer distribution for the lower $1500 \mathrm{~m}$ of the troposphere and illustrates the advection from the southwestern coast of France (Bordeaux, in source region B) into the BC for both episodes (Figs. 6a-b). There is also an eastto-west transport, parallel to the northern coast of Iberia, for the remaining coastal emissions from source region B. At 


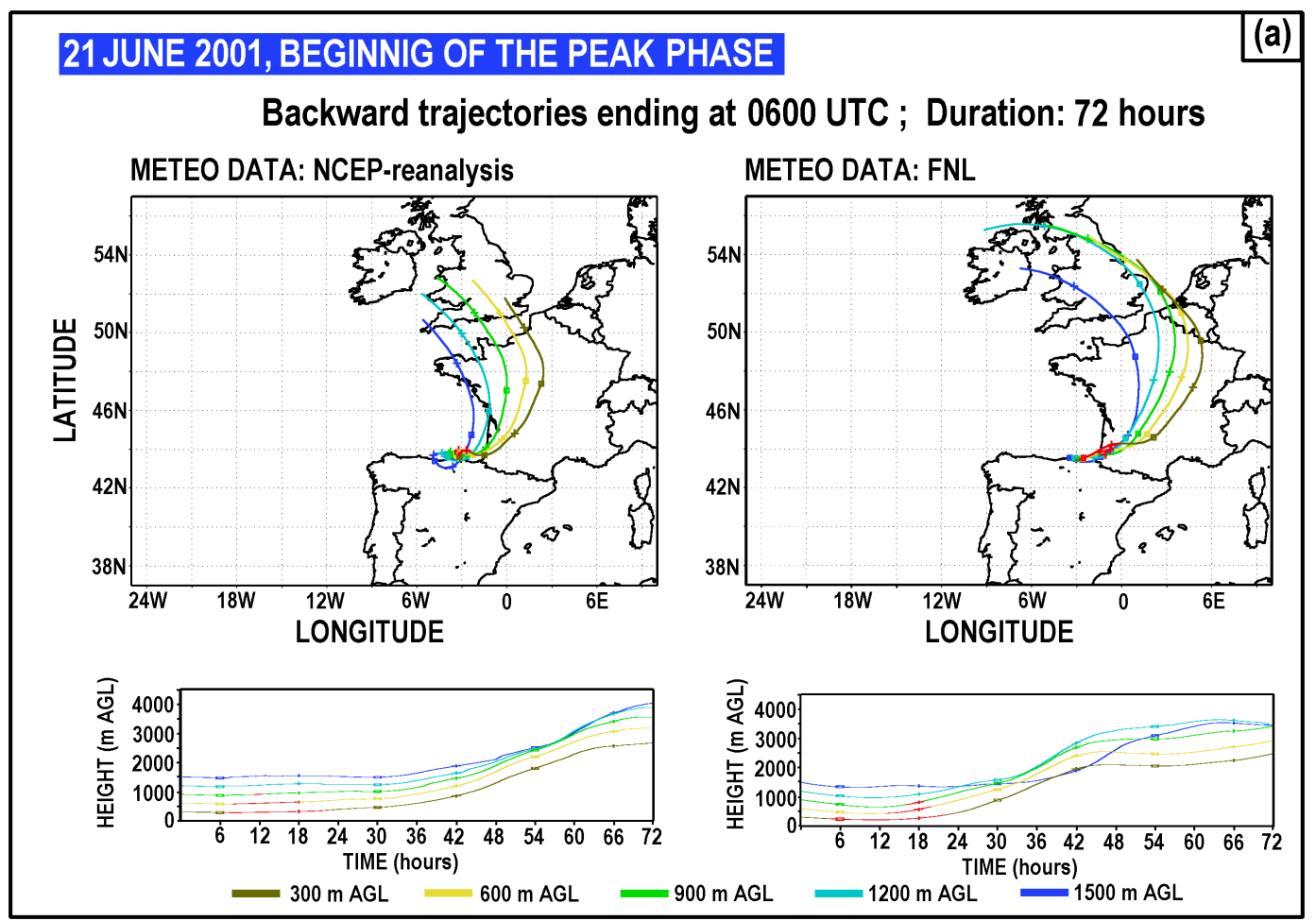

\section{JUNE 2003, BEGINNIG OF THE PEAK PHASE}

Backward trajectories ending at 0600 UTC ; Duration: 72 hours

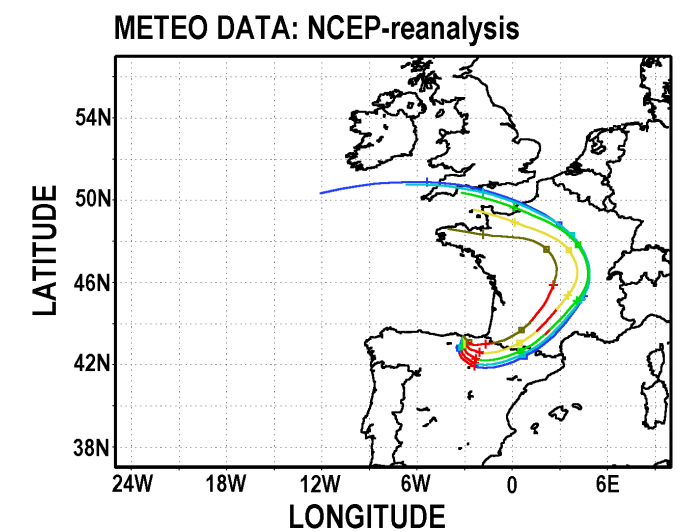

METEO DATA: FNL
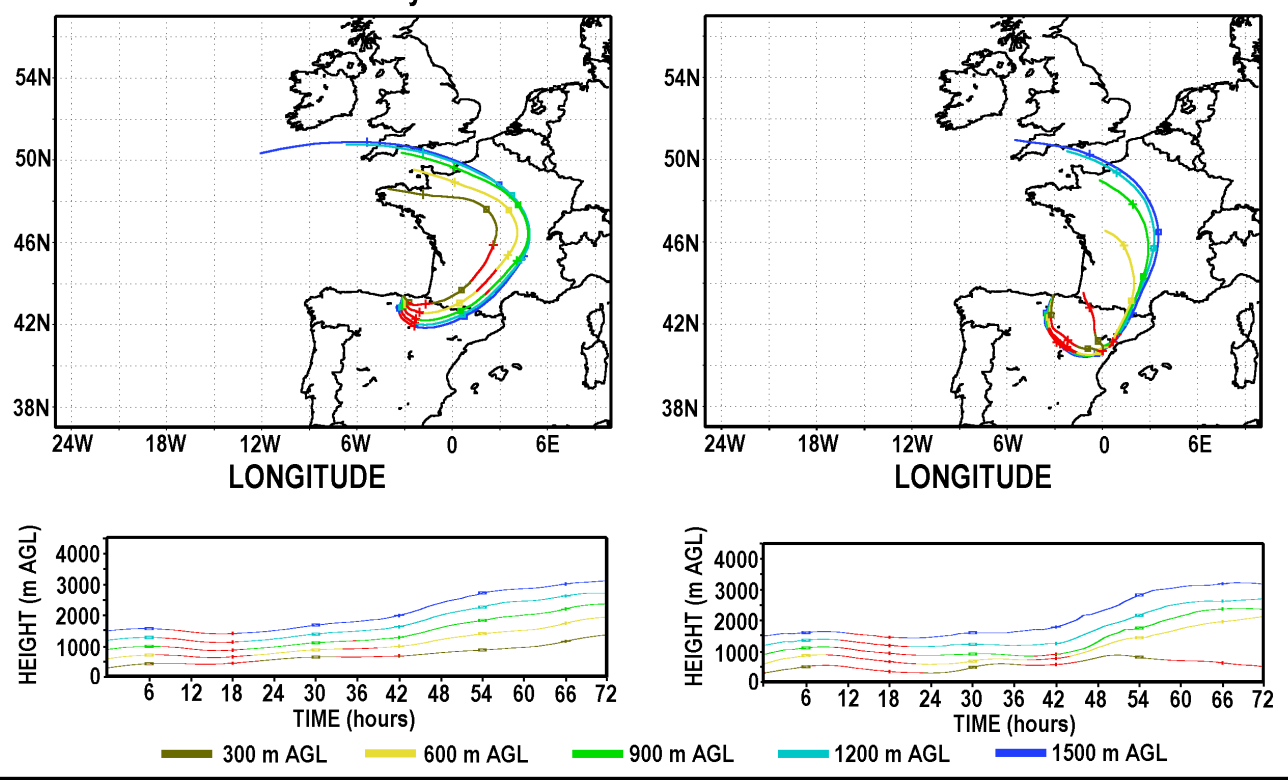

Fig. 9. (a) Back-trajectories arriving at the vertical (300, 600, 900, 1200 and $1500 \mathrm{~m}$ AGL) of the Basque Country coastal area during the peak phase (06:00 UTC, 21 June) of the 2001 episode, calculated using the NCEP-reanalysis (left) and the FNL (right) meteorological data. Trajectories are shown in a longitude-latitude (upper panels) and time-height (lower panels) projections. Crosshairs and open squares on the trajectories mark midday and midnight times, respectively (b) Same for the June 2003 episode (06:00 UTC, 21 June). 


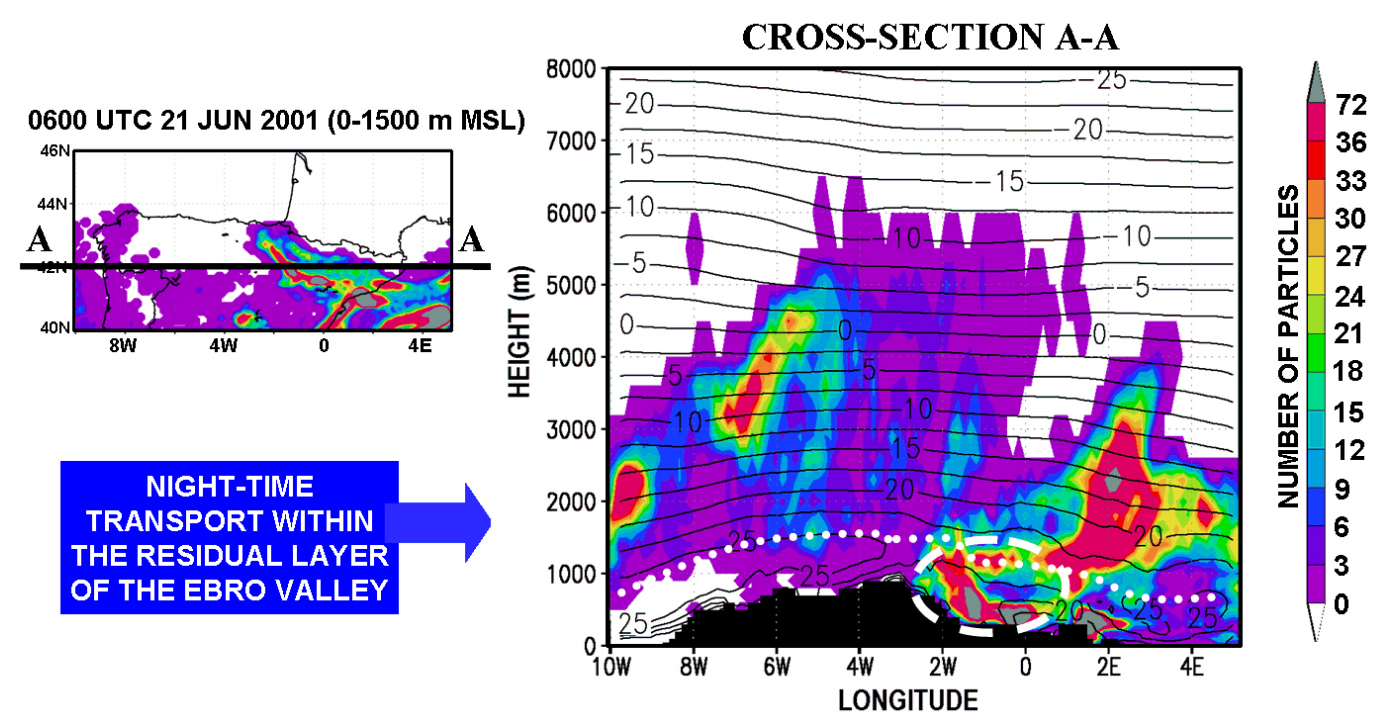

Fig. 10. Vertical cross-section of northern Iberia, centred at constant latitude $42^{\circ} \mathrm{N}\left(41.5^{\circ}-42.5^{\circ} \mathrm{N}\right)$ along the Ebro Valley. The vertical tracer distribution, in shaded colours, corresponds to the WM emissions (region D) in Fig. 8a, which is enlarged up to the scale of grid \#2. Contour lines represent vertical distribution of simulated temperatures $\left({ }^{\circ} \mathrm{C}\right)$ and the white dot line outlines the top of the temperature inversion. The particle cloud encircled by the dash line is transported from the Mediterranean into the BC (Atlantic northern coast of Iberia). The terrain profile is represented (in black) in the bottom of the cross-section.

the same time, during this accumulation phase (Figs. 6ab), emissions from the WM (region C and D), including the plumes from the cities of Lyon and Toulouse, do not have a direct impact in northern Iberia and the BC: they enter the WM basin with the Mistral and Tramontana winds and recirculate over the area, trapped in the WM atmospheric gyre (Gangoiti et al., 2001) and the coastal recirculations on the East coast of Iberia (Millán et al., 1996, 1997). Plumes from region A are observed entering the WM through the Carcasonne gap within the Tramontana winds and, then, they initiate a clockwise rotation to point into the Bay of Biscay, resulting in the formation of a vast band of pollution over the northern coast of Iberia, observed 2 days later (beginning of the peak phase in Fig. 8).

Back-trajectories depicted in Fig. 7 show also a continental origin (south-western France) for pollutants arriving at the BC coastal area during the accumulation phase. These trajectories were produced by the HYSPLIT model at the NOAA ARL website using 6-hourly global meteorological data from both the FNL archive of the NCEP Global Assimilation System $($ GDAS $)$ model output $\left(1^{\circ} \times 1^{\circ}\right.$ latitudelongitude grid resolution) and the NCEP-NCAR reanalysis archive $\left(2.5^{\circ} \times 2.5^{\circ}\right.$ latitude-longitude $)$. Five trajectories with a duration of $48 \mathrm{~h}$ and ending at 300,600, 900, 1200 and $1500 \mathrm{~m}$ AGL are estimated for each run. The vertical motion is calculated using the model vertical velocity and the red colour is used for trajectories inside the mixing height. The latter variable is read from the meteorological archived data. Therefore, read-coloured trajectory fractions show po- tential locations for both ground impact of transported pollutants and the up-take of pollution from surface sources. Results shown in Figs. 7a-b do not substantially differ from the RAMS-HYPACT analysis: the accumulation phase for both episodes begins with the import of pollutants from southwestern France. Yet there are differences between the FNL and the NCEP-reanalysis trajectories: the FNL lower trajectories are inside the mixing height in south-western France, while the reanalysis trajectories are not, and consequently there is no up-take mechanism for pollutants emitted from surface sources in France to be transported with the latter trajectories.

\subsection{Peak phase}

Following the high-resolution results of the RAMSHYPACT modelling system, during the morning of the peak day of both episodes, emissions from different source regions reach the $\mathrm{BC}$ simultaneously. Figure 8 shows the tracer distributions for the 4 source regions (A-to-D) during the start of the peak day for both episodes (early morning conditions). The figure shows again the particle burden for the lower $1500 \mathrm{~m}$ of the troposphere. At this time, both the WEA region (Fig. 8, source regions A-B), mainly from southern France and the English Channel, and the Mediterranean region (Fig. 8, source regions C-D) are contributing to the increase in ozone concentrations at the $\mathrm{BC}$ monitoring network (Fig. 2). However, the back-trajectory analysis, which was performed following the same scheme described in the previous section, with a longer duration of $72 \mathrm{~h}$ shows different 


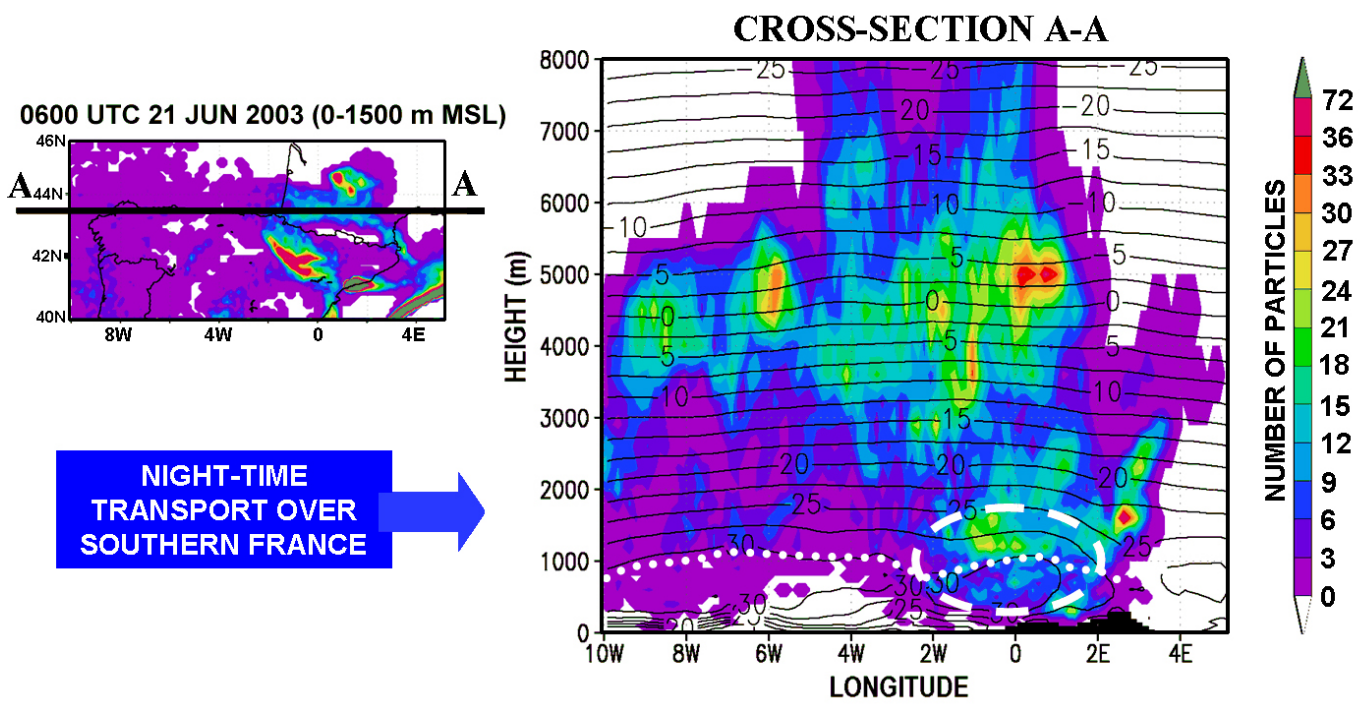

Fig. 11. Vertical cross-section of northern Iberia, centred at constant latitude $43.5^{\circ} \mathrm{N}\left(43^{\circ}-44^{\circ} \mathrm{N}\right)$ along the northern flanks of the Pyrenees. The vertical tracer distribution, in shaded colours, corresponds to the WM emissions (region D) in Fig. 8b, which is enlarged up to the scale of grid \#2. Contour lines represent vertical distribution of simulated temperatures $\left({ }^{\circ} \mathrm{C}\right)$ and the white dot line outlines the top of the temperature inversion. The particle cloud encircled by the dash line is transported from the Mediterranean into the BC. The terrain profile is represented (in black) in the bottom of the cross-section.

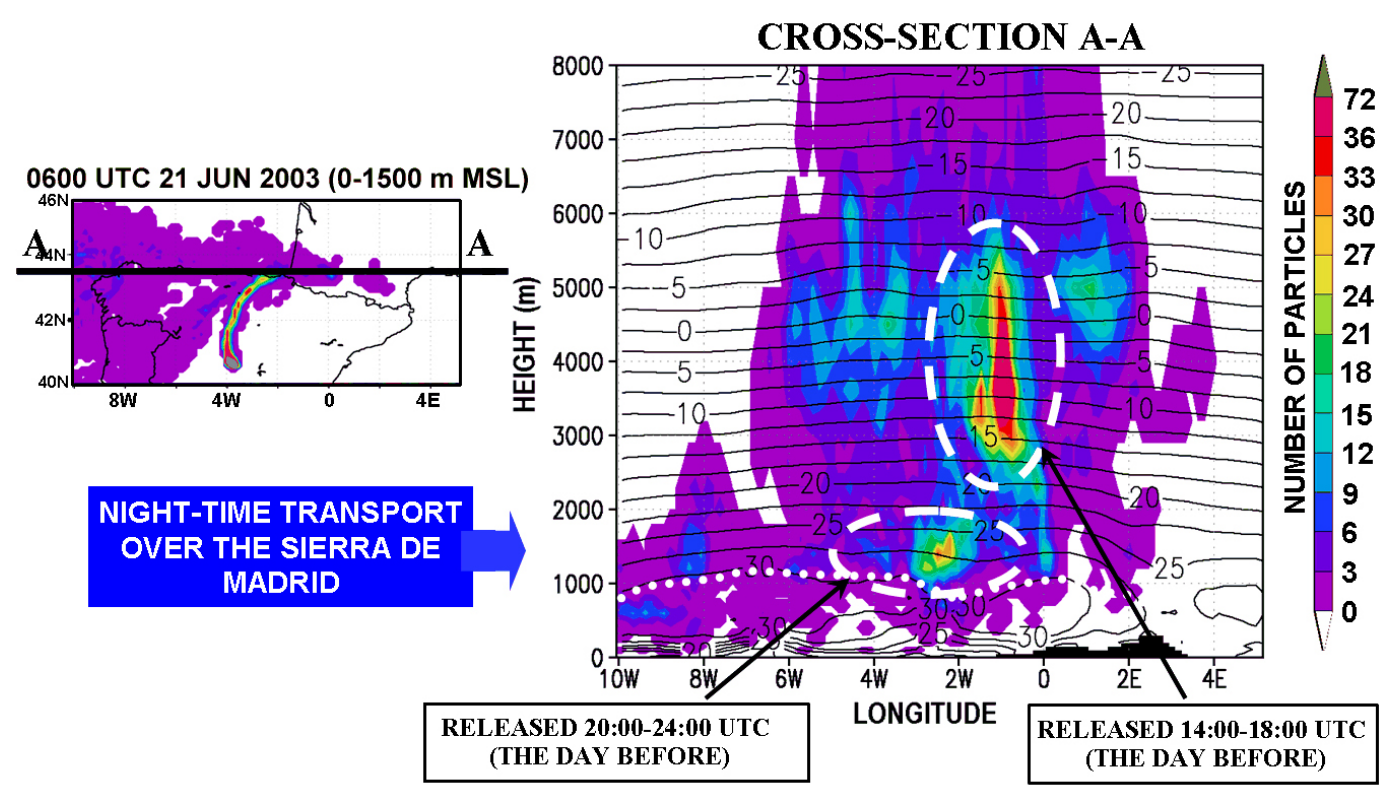

Fig. 12. Same as Fig. 11, but for the tracer released from the city of Madrid (the plan view of the Madrid plume at the lower $1500 \mathrm{~m}$, is also observed in Fig. 8b, region B). The major fraction of the plume is transported at a high altitude (3000-5000 m) by the southerly winds blowing at that height. That fraction was vented the day before to the middle troposphere by the up-slopes winds at the Sierra de Madrid mountains (Fig. 1). A smaller fraction located on top the subsidence inversion, between 1000-1500 m, reaches the northern coast of Spain (at the vertical of the BC) after night-time transport over the Sierra de Madrid.

results depending on the meteorological data used for the calculation: while the trajectories calculated with the NCEPreanalysis data point to a similar origin (in southern France) for the ozone background increase during the peak phase and the accumulation phase (Sect. 5.1), the FNL results show an intrusion from the Ebro valley during the June 2003 episode, 


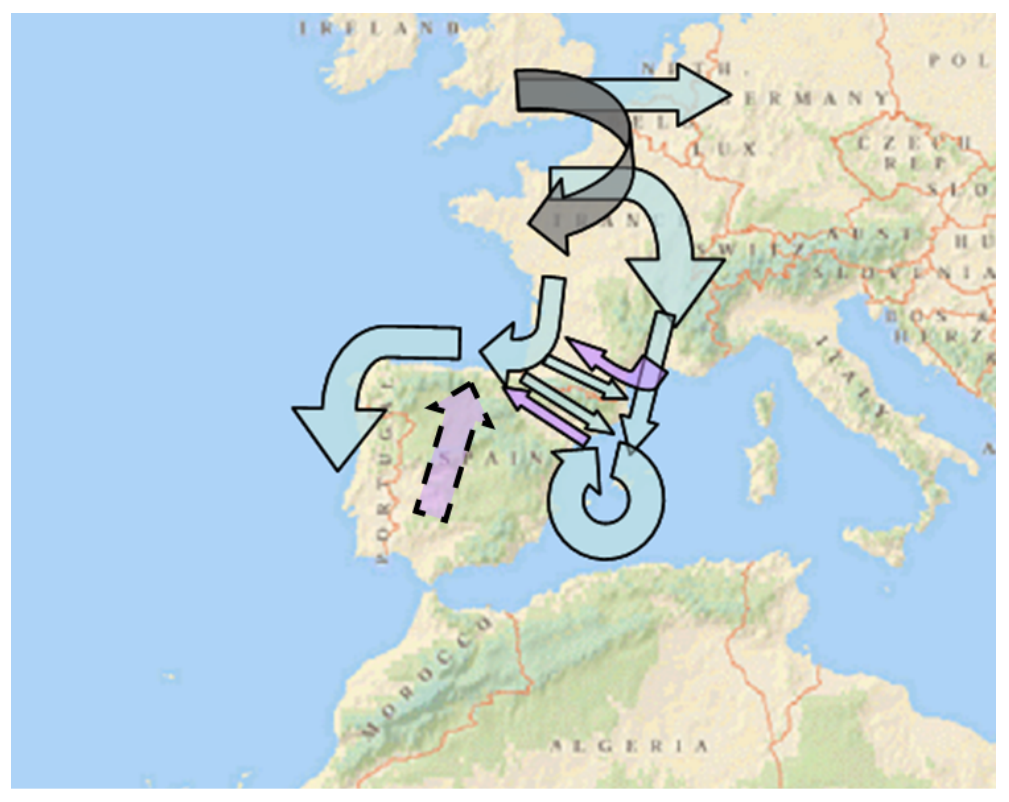

Fig. 13. Main pathways documented during both the accumulation and peak phases of the episodes: the figure represents the transition of the northern emissions following the evolution of the high pressure system into the European continental area, the coastal migration of the polluted air mass at the northern and western coast of Iberia, the circulation in the WM basin, and the inter-transport of pollution between the WM and the Bay of Biscay (Atlantic Ocean) at the flanks of the Pyrenees: from the Atlantic into the Mediterranean, before and during the onset of the accumulation phase, and in the opposite direction during the peak phase. The latter pathway, and that from central Iberia (city of Madrid), depicted with a different colour, represent night-time transport under stable layer, before the onset of convection and the subsequent fumigation.

transporting pollutants from the Mediterranean coastal area (the city of Tarragona), where there is a large petrochemical industrial pool. The latter trajectories are more in agreement with the RAMS-HYPACT simulation, which describes a more complex scenario, not only during the peak phase of the June 2003 episode, but also for the 2001 episode. It follows a detailed description of the transport processes during the initiation of the peak phase of both episodes after the high-resolution RAMS-HYPACT simulation.

Most of the pollutants arriving in the BC coastal area from the WEA region are transported in a direct and continuous (day and night) trajectory within the east and north-easterly winds blowing over the Bay of Biscay and the northern coast of Iberia. Then, the polluted air masses over the sea are drawn inland with the onset of the coastal sea-breezes and fumigate on the whole coastal area of northern Iberia. In contrast, the contribution from the WM region (Fig. 8, source regions $\mathrm{C}-\mathrm{D}$ ) follows night-time trajectories over land, using both a pathway over the Ebro valley, from the WM into the Atlantic Ocean (Bay of Biscay) and an east-to-west trajectory over southern France, parallel to the northern flanks of the Pyrenees (June 2003 episode in Fig. 8, C-D). Night-time trajectories over the Ebro valley were first documented by Gangoiti et al. (2002) during a similar high-pressure blocking scenario in June 1996, and occur in all the analyzed episodes during the early-morning conditions of the peak phase. The arrival of the polluted air masses from the Mediterranean are favoured by the night-time stabilization of the surface layer over land and the evolution eastward of the high pressure system over the British Isles. These processes force the drainage of the residual layer on both the Ebro valley (Fig. 10) and the northern flanks of the Pyrenees (Fig. 11), located on top of the stably stratified surface layer and under the high pressure subsidence inversion, into the Bay of Biscay. Thus, ozone and precursors are transported to the $\mathrm{BC}$ during the night and early morning of the peak day, and they then fumigate on the coastal and inland areas, with the onset of daytime convection and the sea-breeze regime. A fraction of the tracer transported from the WM basin into the Bay of Biscay in Figs. 10 and 11 is also located within and just over the subsidence inversion (1000-1200 m MSL) and also fumigates during the onset of day-time convection along the northern coast.

The plume from the city of Madrid is observed in the early morning of the peak day in the June 2003 episode (Fig. 8, source region B) pointing northward. This is not the case for the June 2001 episode. However, southerly winds over central Iberia are frequent at the mature phase of this type of episodes and the plume from Madrid can also contribute to an increase in ozone concentrations in northern Iberia. The main fraction of the plume from Madrid crosses the northern coast of Iberia between the $3000-5000 \mathrm{~m}$ height in the crosssection of Fig. 12. This fraction was released between 14:00- 
18:00 UTC the day before, and crossed the Sierra de Madrid (the mountain range at the northern boundaries of the city), under unstable conditions. The plume was vented to the middle troposphere by the up-slope winds at this mountain range. However, the plume fraction observed between $1000-1500 \mathrm{~m}$ was released $6 \mathrm{~h}$ later (20:00-24:00 UTC) and crossed the Sierra de Madrid under stable conditions, reaching the northern coast after a night-time transport. This fraction also contributed to increased ozone concentrations on the peak day in the June 2003 episode, after fumigation within the convection cells of the mountain ranges on the northern coast of Iberia.

\section{Summary and conclusions}

A modelling system based on the mesoscale model RAMS coupled with the dispersion model HYPACT was used to reproduce the transport dynamics during two ozone episodes in the BC, with similar dispersion scenarios. The main pathways for the accumulation and peak phases of the episodes, from the different source regions, are summarized in Fig. 13. Backward trajectories obtained by using meteorological data currently available from global analysis (coarse grids of 1to-2.5 degrees latitude-longitude with 6-h time resolution) does not explain the origin and the main atmospheric processes responsible for the transport of pollutants during the peak phase of both episodes. The main pollution sources and transport dynamics can be summarized as follows:

1. During the accumulation phase, the increase in ozone background levels in the $\mathrm{BC}$ monitoring network is concurrent with the tracer arrival from sources in the WEA region. Day and night transport of pollutants has been documented within the east and north-easterly winds forced by the WEA anticyclone, mainly from the west coast of France (direct-short pathway for the WEA northern plume). Ozone and precursors follow trajectories over the sea, before reaching the $\mathrm{BC}$ coastal area within and over a stably stratified marine boundary layer. Local pollution together with coastal advection is drawn inland by the sea breezes and up-slopes winds.

2. During the peak phase, new external regions contribute to both local production and coastal advection:

- During the early morning, emissions from the English Channel and western France are spread over a large area over the Bay of Biscay and north-western Iberia. These plumes follow a clockwise rotation during the eastward evolution of the anticyclone, and then they are drawn inland following the onset of the coastal sea-breezes and the development of the Iberian thermal low (Millán et al., 1991, 1997; Alonso et al., 2000)
- At the same time (early morning hours of the peak day), emissions from the WM source region are observed travelling over the Ebro valley onto the northern coast of Iberia. This type of discharge occurs after the onset of favourable pressure gradients between the Mediterranean and the northern Atlantic in the mature phase of the WEA anticyclone. Surface air at the bottom of the Ebro valley is stagnant or following a weak "natural drainage" into the Mediterranean. However, the residual layer on top, which accumulates pollutants emitted inside the valley on the previous day as well as those drawn by the Mediterranean sea-breezes, discharges onto the northern coast of Iberia. A similar type of night-time discharge from the WM source region onto the BC occurs simultaneously along the northern flanks of the Pyrenees during the June 2003 episode. These intrusions seem to be less frequent than those from the southern flanks (Ebro valley).

- The Pyrenees (northern and southern flanks) pathways between the Mediterranean and the Bay of Biscay can also be used by pollutants from the European continental area and the English Channel. These pollutants, following the Tramontana and Mistral winds, enter the WM region between the Pyrenees and the Alps during the accumulation phase (Fig. 6). Subsequent circulations within the WM gyre and the Eastern Iberian sea-breezes can re-direct part of the WEA northern plume westward so that it can participate in the night-time transport from the northern and southern flanks of the Pyrenees.

- The plume from the city of Madrid also contributes to the increase in ozone concentrations in the BC during the peak day of the June 2003 episode: southerly winds can develop over central Iberia during the mature phase of the WEA anticyclones, and, under night-time conditions emissions from this important source area can cross the Sierra de Madrid mountains within stably stratified layers and with limited dilution (Fig. 12). This plume arrives at the northern coast, at a level reachable by daytime convection (1000-1500 m MSL), early the next morning, and after the onset of convection, it fumigates within the mountain range of the northern coast.

Acknowledgements. The authors wish to thank the Department of the Environment and the Meteorological Service of the Basque Government for providing the air quality and meteorological data. Financing was provided by the National Research Program of the Spanish Ministry of Education and Science: project TRAMA (CGL2004-04448). The authors wish also to acknowledge the NOAA Air Resources Laboratory (ARL) for the provision of the HYSPLIT transport and dispersion model and the READY website 
(http://www.arl.noaa.gov/ready.html) used in this publication.

Edited by: F. J. Dentener

\section{References}

Albizuri, A.: Clasificación de patrones meteorológicos y su relación con los episodios de ozono en la CAPV, in: Proceedings of the IX Congress of Environmental Engineering, Published by the Bilbao Exhibition Centre and the University of the Basque Country, Bilbao, Spain, 441-451, 2004.

Albizuri, A.: Classification of meteorological patterns and its relation with the ozone episodes in the Basque Country, edited by: Sokhi, R. S., Millán, M. M., and Moussiopoulos, N., Proceedings of the 5th International Conference on Urban Air Quality (UAQ2005), Published by the University of Hertfordshire (U.K.), Valencia, Spain, 100-103, 2005.

Alonso, L., Gangoiti, G., Navazo, M., Maruri, M., García, J. A., and Aranda, J. A.: The Punta Galea boundary layer profiler: intercomparison with radiosonde data and first mesoscale meteorological case studies, Meteorologische Zeitschrift, N. F, 7, H.5, 203-212, 1998.

Alonso, L., Gangoiti, G., Navazo, M., Millán, M. M., and Mantilla, E.: Transport of tropospheric ozone over the Bay of Biscay and the Eastern Cantabrian coast of Spain, J. Applied Meteorology 4, 475-486, 2000.

Brönnimann, S., Siegrist, F. C., Eugster, W., Cattin, R., Sidle, C., Hirschberg, M. M., Schneiter, D., Perego, S., and Wanner, H.: Two case studies on the interaction of large-scale transport, mesoscale photochemistry, and boundary-layer processes on the lower tropospheric ozone dynamics in early spring, Ann. Geophys., 19, 469-486, 2001.

de Leeuw, F. and Bogman, F.: Air pollution by ozone in Europe in summer 2003, EEA Topic report No13/2001, European Environment Agency, Copenhagen, 2001.

Draxler, R. R. and Rolph, G. D.: HYSPLIT (HYbrid Single-Particle Lagrangian Integrated Trajectory) Model access via NOAA ARL READY Website (http://www.arl.noaa.gov/ready/hysplit4.html), NOAA Air Resources Laboratory, Silver Spring, MD, 2003.

Draxler, R. R.: Evaluation of an Ensemble Dispersion Calculation, J. Appl. Meteorol., 42, 2, 308-317, 2003.

Durana, N., Navazo, M., Gómez, M. C., Alonso, L., García, J. A., Ilardia, J. L., Gangoiti, G., and Iza, J.: Six years of measurements of speciated nonmethane hydrocarbons in Bilbao (Spain), in: Sokhi R. S., Millán, M. M., and Moussiopoulos, N., Proceedings of the 5th International Conference on Urban Air Quality (UAQ), Published by the University of Hertfordshire (U.K.), Valencia, Spain, 93-96, 2005.

Environment and Systems: Photochemical pollution in the Basque Country Autonomous Community, Servicio Central de Publicaciones del Gobierno Vasco, Departamento de Ordenación del Territorio, Vivienda y Medio Ambiente, Vitoria-Gasteiz, Spain, 1999.

Fiala, J., Cernikovsky, L., de Leeuw, F., and Kurfuerst, P.: Air pollution by ozone in Europein summer 2003, EEA Topic report No3/2003, European Environment Agency, Copenhagen, 2003.

Gangoiti, G., Millán, M. M., Salvador, R., and Mantilla, E.: Longrange transport and re-circulation of pollutants in the Western
Mediterranean during the RECAPMA Project, Atmos. Environ., 35, 6267-6276, 2001.

Gangoiti, G., Alonso, L., Navazo, M., Albizuri, A., Pérez-Landa, G., Matabuena, M., Valdenebro, V., Maruri, M., García, J.A., and Millán, M. M.: Regional transport of pollutants over the Bay of Biscay: analysis of an ozone episode under a blocking anticyclone in west-central Europe, Atmos. Environ., 36, 1349-1361, 2002.

Kallos, G., Kotroni, V., Lagouvardos, K., and Papadopoulos, A.: On the long-range transport of air pollutants from Europe to Africa, Geophys. Res. Lett., 25, 5, 619-622, 1998.

Millán, M. M., Artíñano, B., Alonso, L., Navazo, M., and Castro, M.: The effect of meso-scale flows on regional and long-range atmospheric transport in the western Mediterranean area, Atmos. Environ., 25A, 949-963, 1991.

Millán, M. M., Salvador, R., Mantilla, E., and Artínano, B.: Meteorology and photochemical air pollution in southern Europe: Experimental results from EC research projects, Atmos. Environ., 30, 1909-1924, 1996.

Millán, M. M., Salvador, R., Mantilla, E., and Kallos, G.: Photooxidant dynamics in the Western Mediterranean in summer: Results from European research projects, J. Geophys. Res., 102, D7, 8811-8823, 1997.

Millán, M. M., Mantilla, E., Salvador, R., Carratala, A., Sanz, M. J., Alonso, L., Gangoiti, G., and Navazo, M.: Ozone cycles in the western Mediterranean basin: interpretation of monitoring data in complex terrain, J. Appl. Meteorol.,4, 487-507, 2000.

Navazo, M., Durana, N., Gómez, M. C., Alonso, L., García, J. A., Ilardia, J. L., Gangoiti G., and Iza, J.: Ozone precursors in rural areas: Valderejo natural park (Northern Spain): A two year's study, edited by: Sokhi R. S., Millán, M. M., and Moussiopoulos, N. , Proceedings of the 5th International Conference on Urban Air Quality (UAQ), Published by the University of Hertfordshire (U.K.), Valencia, Spain, 128-131, 2005.

Palau, J. L., Pérez-Landa, G., Meliá, J., Segarra, D., Diéguez, J. J., and Millán, M. M.: Characterization of the dispersion of a power plant plume on complex terrain under winter conditions, Proceedings of the 9th Int. Conf. on Harmonization within Atmospheric Dispersion Modelling for Regulatory Purposes, Garmisch-Partenkirchen, Germany. http://imk-ifu.fzk.de/ harmo9/, 2004.

Pielke, R. A., Cotton, W. R., Walko, R. L., Tremback, C. J., Lyons, W. A., Grasso, D., Nicholls, M. E., Moran, M. D., Wesley, D. A., Lee, T. L., and Copeland, J. H.: A comprehensive meteorological modelling system -RAMS. Meteorol. Atmos. Phys., 49, 69-91, 1992.

Reynolds, R. W. and Smith, T. M.: Improved global sea surface temperature analyses using optimum interpolation , J. Clim., 7, 929-948, 1994.

Rolph, G. D.: Real-time Environmental Applications and Display sYstem (READY) Website (http://www.arl.noaa.gov/ready/ hysplit4.html). NOAA Air Resources Laboratory, Silver Spring, MD, 2003.

Tremback, C. J., Lyons., W. A., Thorson, W. P., and Walko, R. L.: An emergency response and local weather forecasting software system, edited by: Gryning, S. and Millán, M. M., Proceedings of the 20th ITM on Air Pollution and its Application, Plenum Press, New York, 423-429, 1993. 